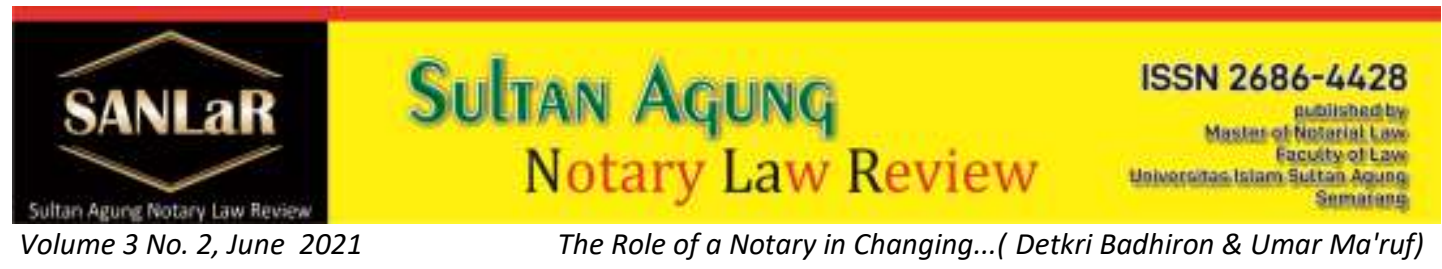

\title{
The Role of a Notary in Changing the Name of a Limited Liability Company
}

\author{
Detkri Badhiron ${ }^{*}$ and Umar Ma'ruf**) \\ ${ }^{*}$ Managing Partner of DPNK Law Firm, E-mail: www.dpnklawfirm.com \\ ${ }^{* *}$ Faculty of Law, Universitas Islam Sultan Agung (UNISSULA) Semarang, E-mail: \\ umar@unissula.ac.id
}

Abstract. This research aims to know and analyze the factors that cause PT. Mega Transformation Indonesia turned into PT. Djaja Bangun Rahardja, besides that this research is also to find out and analyze the role of the Notary in changing PT. Mega Transformation of Indonesia into PT. Djaja Bangun Rahardja was connected with Act No. 40 of 2007 concerning Limited Liability Companies and the last one was to identify and analyze the process of obstacles and solutions in the process of changing PT. Mega Transformation Indonesia into PT. Djaja Bangun Rahardja is associated with Act No. 40 of 2007 concerning Limited Liability Companies. The approach method in this research is empirical juridical. The juridical approach (law is seen as a norm or das sollen), because in discussing the problem this research uses legal materials (both written law and unwritten law or both primary legal materials and secondary legal materials). Empirical approach (law as a social, cultural or das sein reality), because in this study primary data obtained from the field were used. So, the empirical juridical approach in this study means that in analyzing the problem, it is done by combining legal materials (which are secondary data) with primary data obtained in the field, namely about how the role of Notaries requires empirical research on Notaries who process changes in names of shareholders and changes to the Board of Directors. The specifications used in this research are descriptive analytical, which is intended to provide data as accurate as possible about a situation or other symptoms. Because this research is expected to provide a detailed, systematic and comprehensive description of the role of a Notary in processing the name change of a limited liability company. The data required includes Primary data is data obtained from the field, data obtained from respondents. Respondents are people or people who provide answers to questions from researchers. Secondary data is data obtained from or derived from library materials, secondary data collected in this study include primary legal materials, secondary legal materials and tertiary legal materials. In discussing the subject matter and analyzing the data that has been obtained, the authors use all the information and data that have been obtained, both primary 
data and secondary data. Then the writer analyzes qualitatively which is then presented descriptively.

Keywords: Role; Notary; Limited Liability Company.

\section{Introduction}

The position of a Notary as a functionary in society is still highly respected. Notary as an official, is a place for someone to get reliable advice. Everything written and determined (constantir) is true, he is a strong document maker in the legal process. Every society needs a (figure) whose information is reliable, trustworthy, whose signature and seal (stamp) provide strong guarantees and evidence, an impartial expert and impeccable legal adviser (onreukbaar or unimpeachable), who keeps his mouth shut and make a pact that can protect him in the days to come ${ }^{1}$.

The Notary profession as part of the legal profession is considered a very noble and honorable profession, because the purpose of the legal profession is to uphold law and justice in people's lives. ${ }^{2}$ So that it makes people believe ${ }^{3}$ in the notary profession ${ }^{4}$, so that every aspect of life, both social and business, requires the role of a Notary in the relationship between people.

Communities and business actors in this modern era, legal protection in the economic sector between individuals or groups of people is very much needed to ensure security and comfort in doing business, this is motivated by the need for written proof of agreements between humans which are then poured in the form of a deed issued by Notary Public. This is one of the legal protections in the business world, both between individuals and groups.

This is as described in Article 1 of Act No. 2 of 2014 Amendment to Act No. 30 of 2004 concerning the Position of Notary which provides provisions regarding the definition of a notary, namely: "Notary is a public official who is authorized to make authentic deeds and has other authorities as referred to in this Law or based on the law:

\footnotetext{
${ }^{1}$ Soekanto Soerjono \& Mamuji Sri, (2001), Penelitian Hukum Normatif suatu tinjauan singkat, Jakarta: Raja Grafindo Persada, p. 449.

${ }^{2}$ Tan Thong Kie, Studi Notariat dan Serba-Serbi Praktek Notaris, PT. Ichtiar Baru Van Hoeve, Jakarta, 2007p. 33

${ }^{3}$ Yulies Tiena Masriani, Kedudukan Hukum Akta-Akta Notaris Dalam Ekonomi Islam, Serat AcityaJurnal IImiah, 2013, p. 33

${ }^{4}$ Henny Saida Florida, Peran Notaris Dalam Pembuatan Akta Pendirian dan Akta Perubahan Anggaran Dasar Koperasi, Jurnal Saintech, 2014, p. 61.
} 
The general authority of a notary is regulated in Article 15 paragraph (1), Act No. 30 of 2004 as amended by Act No. 2 of 2014 concerning the Position of a Notary, the authority is "Notaries have the authority to make authentic deeds regarding all acts, agreements, and stipulations required by laws and regulations and/or desired by the interested parties to be stated in an authentic deed, guaranteeing the certainty of the date of making the deed, keeping the deed, providing grosse, copies and quotations of the deed, all of this as long as the making of the deed is not assigned or excluded to other officials or other persons stipulated by law" ${ }^{5}$

That the authority of the Notary to create and protect the rights of the community and it is undeniable that the economic needs of the community continue to develop. Agreements are one of the activities that are most often made by Notaries in order to protect economic legal actions in society, and cannot be denied.

Today the need for a notary, especially in the business sector, especially Limited Liability Companies as a legal entity, by the global community today is a primary need, because with the intervention of a notary, legal protection can be achieved in addition to fulfilling the provisions of the law, in this particular case. Limited Liability Company Law. Thus the presence of an authentic deed which is a legal product born by a notary is a supporter of the creation of the concept of legal certainty which is the foundation of justice.

Limited Liability Company as a legal entity is supported by the existence of various kinds of laws and regulations which are also an indication of government participation or involvement in supporting the world economy as a foundation for the growth and development of a country.

Limited Liability Company (PT) is the most preferred form of economic activity at this time, because in addition to its limited liability, Limited Liability Companies also provide convenience for owners (shareholders) to transfer their company (to everyone) by selling all of their shares in the company and other benefits. ${ }^{6}$

Based on what has been described above, the authors identify that the change in the name of the company and the composition of shareholders will certainly have an impact on the composition of the Board of Directors and Commissioners, although there are no problems in the turnover process, but on the legal side it will meet many obstacles and obstacles.

\footnotetext{
${ }^{5}$ Ngadino, Tugas dan Tanggung Jawab Jabatan Notaris di Indonesia, Universitas PGRI Semarang Press, Semarang, 2019, p. 9

${ }^{6}$ Ahmad Yani dan Gunawan Widjaja, Perseroan Terbatas,: PT. RajaGrafindo Persada, Jakarta, 2003, p. 1.
} 


\section{Research Methods}

In a research method is one of the factors for the problems to be discussed, where the research method is the main way that aims to achieve the level of accuracy of the number and type to be achieved. As a scientific work, this research has the aim of revealing the truth in a methodological and consistent manner in legal research, a scientific activity based on certain systematics and thoughts by analyzing it. ${ }^{7}$

In carrying out this research, the authors use the following methodology:

\section{Approach Method}

The method used in this paper is empirical juridical. The juridical approach (law is seen as a norm or das sollen), because in discussing the problem this research uses legal materials (both written law and unwritten law or both primary legal materials and secondary legal materials). Empirical approach (law as a social, cultural or das sein reality), because in this study primary data obtained from the field were used. So,

\section{Research Specification}

The specifications used in this research are descriptive analytical, which is intended to provide data as accurate as possible about a situation or other symptoms. ${ }^{8}$, because this research is expected to provide a detailed, systematic and comprehensive description of the role of a Notary in processing the name change of a limited liability company.

\section{Data Types and Sources}

In this study the authors use the types of primary data and secondary data, as follows:

a. Primary data is data obtained from the field, data obtained from respondents. Respondents are people or people who provide answers to questions from researchers.

b. Secondary data is data obtained from or derived from library materials, secondary data collected in this study include primary legal materials, secondary legal materials and tertiary legal materials.

1. Primary legal materials are legal materials in the form of legal norms that have a binding nature. In this study used, among others:

- 1945 Constitution

- Code of Civil law

\footnotetext{
${ }^{7}$ Khudzaifah Dimyati and Kelik Wardiyono, Metode Penelitian Hukum, FH UMS, 2004, p. 3.

${ }^{8}$ Soerjono Soekanto \& Sri Mamuji, Penelitian Hukum Normatif Suatu Tinjauan Singkat, Jakarta: Raja Grafindo Persada, 2001, p. 43.
} 
- Act No. 2 of 2014 concerning Amendments to Act No. 30 of 2004 concerning the Position of a Notary.

- Act No. 40 of 2007 concerning Limited Liability Companies

- Regulation of the Minister of Law and Human Rights of the Republic of Indonesia Number: M-01-HT.01-10 of 2007 concerning Procedures for Application for Legal Entity and Approval of Amendments to the Articles of Association, Submission of Notification of Articles of Association and Changes to Company Data

2. Secondary Legal Materials are legal materials that are not in the form of legal norms, but are in the form of expert opinions, this material can be obtained from legal literature or books, magazines, newspapers, internet, written works of scholars in the form of theses, theses and dissertations.

3. Tertiary Legal Materials are materials that provide instructions or explanations for primary and secondary legal materials, in this study are the Big Indonesian Dictionary, Legal Dictionary, and Encyclopedia.

4. Data collection technique

In this study the authors use data collection techniques as follows:

\section{Interview (interview)}

Interview is a way to obtain information by asking directly to the interviewee, and is a process of interaction and communication. ${ }^{9}$ This interview was conducted with the aim of obtaining data or information on people who are considered to know and it is possible to obtain useful and accountable data for the truth. In this study the authors conducted interviews at the Notary's Office in Yogyakarta.

\section{Literature review}

This method is done by doing a series of things such as reading, studying, taking notes, and making reviews of library materials that are related to the problems to be studied.

\section{Document Study}

Document studies are resources used to complete research, in the form of written sources, pictures (photos), and monumental works, all of which provide information for the research process.

5. Data analysis

In discussing the subject matter and analyzing the data that has been obtained, the authors use all the information and data that have been obtained, both primary data and secondary data. Then the writer analyzes qualitatively which is then presented descriptively.

${ }^{9}$ Ronny Hanitijo Soemitro, Metode Penulisan Hukum dan Jurimetri, Semarang : Ghalia Indonesia, 1998, p. 57 


\section{Results and Discussion}

3.1. The role, authority and obligations of the Notary in the mechanism for making the deed of establishment of a Limited Liability Company

Notaries who carry out state duties, who carry out positions to carry out part of the activities of state duties in the field of civil law and the authority to make authentic deeds requested by the parties who appear before a notary. ${ }^{10}$ Article 1871 of the Civil Code which reads "An authentic deed does not provide perfect evidence of what is contained in it as a mere narrative other than that what is said is directly related to the main content of the deed.

Notaries in carrying out their positions are guided by the provisions of the legislation that exist in the position of a notary attached to two positions as state officials who have duties and functions other than as an official making authentic deeds and as officials making land deeds. The provisions governing the duties and functions as officials making land deeds are regulated in Act No. 30 of 2004 in conjunction with Act No. 2 of 2014 concerning the Position of a Notary, while the provisions regarding the duties and functions as an official making land deeds are regulated in PP No. 37 of 1998 concerning the official making land deeds (PPAT).

Regarding the position of a notary, he has the duty to provide legal certainty services in the form of making authentic deeds and making land deeds. In his duties, there are 2 (two) main functions, namely, firstly, notaries have legal certainty to the community for each ratification of legal bindings, and both notaries have the authority given by law as state officials to provide legal reinforcement for legal bindings. Which in the end provides peace and security to the community.

The responsibilities of a notary can be described theoretically, namely: etymologically (grammar) responsibility comes from the English language, namely "Responsibility" which means responsibility, responsibility or those who have responsibility. Liability means the obligation to provide an answer which is a calculation of all things that occur and the obligation to provide recovery for losses that may be caused. ${ }^{11}$

The notary in the process asks for requirements to change the name of PT:

\footnotetext{
${ }^{10}$ Habib Adji, Sekilas Dunia Notaris \& PPAT Indonesia (Kumpulan Tulisan), Mandar Maju, 2009, Bandung, p.16

${ }^{11}$ F. Sugeng Istanto, Hukum Internasional, UAY Press. Jogjakarta 1994, p.77
} 
a. The name change of PT is a form of amendment to the articles of association, therefore it must go through the mechanism of the General Meeting of Shareholders ("GMS").

b. The GMS to amend the articles of association can be held if at the meeting at least $2 / 3$ (two thirds) of the total shares with voting rights are present or represented at the GMS and the resolution is valid if approved by at least $2 / 3$ (two thirds) of the total the votes cast, unless the articles of association specify a quorum of attendance and/or provisions regarding larger GMS decisions.

c. The amendment to the articles of association in the form of a change in the name of the company must obtain approval from the Minister of Law and Human Rights and contained or stated in a notarial deed in Indonesian

d. Applications for approval of amendments to the articles of association are submitted to the Minister, no later than 30 days from the date of the notarial deed containing the amendments to the articles of association. After the 30 day deadline has passed, the application for approval of amendments to the articles of association cannot be submitted or submitted to the Minister.

In the process of changing PT. Mega Transformation Indonesia has carried out the GMS process for the disposal of shares which previously had the same composition among 7 shareholders to only 2 shareholders and 1 majority shareholder. The process of selling the shares has been paid by the surviving shareholders and is stated in the form of minutes and receipts of the sale and purchase of shares. Because one of the majority shareholders then intends to change the company's name to PT. Djaya Bangun Rahardja.

\subsection{Obstacles and Solutions Notary in making the deed of establishment of a Limited Liability Company has carried out the authority and obligations as stipulated in the Act of Notary Position}

As long as PT. Mega Transformation Indonesia has never received any project or work. The spirit of establishing this company is to work together, both private and government, but due to the busyness of each shareholder so that until the 4th year this company was established there was no progress whatsoever and the Board of Directors only struggled with taxes which annually became company obligations.

Some of us have tried projects for the Government, BUMN and the private sector, experienced problems, both operational and internal to the company itself, so that on May 10, 2019 a General Meeting of Shareholders (GMS) was held to sell shares to one of the Directors so far who does not own shares because he has a project in several cities in Indonesia, so the discourse arose that all would sell shares to one of the Directors. 
The next process was followed by a meeting with most of the shareholders present, so that there were $80 \%$ of the shareholders who gathered then an Minutes of the GMS was made containing the sale and disposal of shares, then continued with the making of minutes of the sale and purchase of shares, the negotiation process that took place was that all shareholders requested payment in advance while the buyer will pay after the notarial deed and all the burden of the notary is on the buyer's side. By making the minutes as follows:

RESULTS OF THE EXTRAORDINARY GMS OF SHAREHOLDERS

PT. MEGA TRANSFORMATION INDONESIA at XT SQUERE, YOGYAKARTA

ON FRIDAY, MAY 10, 2009

\section{MEETING AGENDA :}

Amendment to PT. Mega Transformation Indonesia No. 11 dated April 09 2016, Notary Bintari Dyah Ramadhani SH, M.Kn - Bantul in accordance with the Decree of the Minister of Law and Human Rights Number AHU-0019348.AH.01.01.Year 20016 concerning the Establishment of a Limited Liability Company Legal Entity PT Mega Transformasi Indonesia.

\section{Attended this meeting:}

1. Bima Heri Nugraha, who in this Meeting acts as the President Director of PT. Mega Transformasi Indonesia as well as the holder of 2 2,000,000 shares (two million rupiah);

2. Detkri Badhiron, who in this Meeting acts as the President Director of PT. Mega Transformasi Indonesia as well as the holder of 2 2,000,000 shares (two million rupiah);

3. Mohamad Novweni, who in this Meeting acts as the President Commissioner of PT. Mega Transformasi Indonesia as well as the holder of 2 2,000,000 shares (two million rupiah);

4. Heribertus Apriadi, who in this Meeting acted as Commissioner of PT. Mega Transformasi Indonesia as well as the holder of $22,000,000$ 
shares (two million rupiah);

5. Tengku Wahyudi Sapta Putra, who in this Meeting acted as Commissioner of PT. Mega Transformasi Indonesia as well as the holder of 2 shares of 2,000,000 (two million rupiah);

6. Aris Sustiyono, in this Meeting act as the Director of PT. Mega Transformation Indonesia;

Meeting results :

The meeting was attended by $80 \%$ of the shareholders of PT. Mega Transformasi Indonesia along with other invitations with the following results:

1. This GMS was held at the request of Aris Sustiyono as Director of PT Mega Transformasi Indonesia because there will be investors or personals to buy the Company's shares so that they can be used for work.

2. That since the beginning, a shareholder named Ricky Novrico has never been active in the creation of the Company so that the mechanism for the transfer of shares will be acquired according to applicable regulations, while Tengku Hermansyah's shares will be handed over by Tengku Wahyudi SP because he is the older brother of the person concerned.

3. Whereas for the smooth sale of shares and the life of the company, the shareholders agreed to make changes to the Deed of PT. Mega Transformation Indonesia No. 11 dated April 09 2016, Notary Bintari Dyah Ramadhani SH, M.Kn Bantul in accordance with the Decree of the Minister of Law and Human Rights Number AHU-0019348.AH.01.01.Year 20016 concerning the Establishment of a Limited Liability Company Legal Entity PT Mega Transformasi Indonesia.

The meeting authorizes:

\section{Bima Heri Nugraha}

\section{Detkri Badhiron}

Either jointly or individually with the right to transfer this power to another person (substitution) either partially or wholly to pour the Minutes of 
Meeting into a notarial deed and notify the amendment to the Company's Articles of Association to the competent authority and register it with the Ministry. Law and Human Rights, the Ministry of Trade and the Ministry of Forestry and the Environment at the domicile of the Company, for that purpose the recipient of the power of attorney has the right to appear and provide information, make orders to make and sign the necessary deeds/letters and subsequently take all necessary actions which is considered good and useful to solve the above.

Since there are no other matters that need to be discussed in this Meeting, all shareholders jointly close this Meeting at 18.00 West Indonesia Time.

Shareholders

Bima Heri Nugraha

Detkri Badhiron

Mohamad Novweni

Heribertus Apriadi

Tengku Wahyudi Sapta Putra

In the end, everyone agreed on this and then an agenda was made the next day, with an agreement to draft the minutes of sale and purchase and the composition of the new shareholders. The problem that occurred after the GMS was that there were shareholders who were not present who were out of town and could not be contacted and after in consultation with the Notary concerned must sign the minutes and be attached with NPWP and KTP, this is what makes the problem that the sales process of PT. Mega Transformation Indonesia has not been completed until now. Because what is required according to statutory provisions is not fulfilled.

\section{Closing}

The process of changing a company is not as easy as making it because it must be in accordance with applicable laws and regulations, not to mention the differences in desires between shareholders which cause problems in the disposal of shares. The author's suggestion is that if you are going to make changes, the Company must prepare all the requirements in accordance with the applicable laws and regulations. 


\section{References}

Journals:

[1] Henny Saida Florida, Peran Notaris Dalam Pembuatan Akta Pendirian dan Akta Perubahan Anggaran Dasar Koperasi, Jurnal Saintech, 2014.

[2] Yulies Tiena Masriani, Kedudukan Hukum Akta-Akta Notaris Dalam Ekonomi Islam, Serat Acitya-Jurnal IImiah, 2013.

Books:

[1] Ahmad Yani and Gunawan Widjaja, Perseroan Terbatas: PT. RajaGrafindo Persada, Jakarta, 2003.

[2] F. Sugeng Istanto, Hukum Internasional, UAY Press. Jogjakarta 1994.

[3] Habib Adji, Sekilas Dunia Notaris \& PPAT Indonesia (Kumpulan Tulisan), Mandar Maju, 2009, Bandung.

[4] Khudzaifah Dimyati dan Kelik Wardiyono, Metode Penelitian Hukum, FH UMS, 2004.

[5] Ngadino, Tugas dan Tanggung Jawab Jabatan Notaris di Indonesia, Universitas PGRI Semarang Press, Semarang, 2019.

[6] Ronny Hanitijo Soemitro, Metode Penulisan Hukum dan Jurimetri, Semarang: Ghalia Indonesia, 1998.

[7] Soekanto Soerjono \& Mamuji Sri, (2001), Penelitian Hukum Normatif suatu tinjauan singkat, Jakarta: Raja Grafindo Persada.

[8] Soerjono Soekanto \& Sri Mamuji, Penelitian Hukum Normatif suatu tinjauan singkat, Jakarta: Raja Grafindo Persada, 2001.

[9] Tan Thong Kie, Studi Notariat dan Serba-Serbi Praktek Notaris, PT. Ichtiar Baru Van Hoeve, Jakarta, 2007. 